Canadian Journal of Higher Education Revue canadienne d'enseignement supérieur

Volume 46, No. 2, 2016, pages 111 - 126

\title{
Challenging "Size Matters" Messages: An Exploration of the Experiences of Critical Obesity Scholars in Higher Education
}

Erin Cameron

Memorial University

\begin{abstract}
Given that postsecondary institutions are increasingly seen as sites to promote health, critical scholars are calling attention to how the contemporary Western weight-centred health paradigm reinforces a "size matters" message that is fueling harmful attitudes towards and judgments of bodies. As such, research that highlights strategies to promote safe teaching and learning environments for students and faculty, regardless of body shape and size, is of utmost importance. Through 26 participant interviews, this study examines the experiences of critical obesity scholars who teach courses that engage critical approaches to obesity, fatness, and body size. The findings of this study shed light on the developing field of critical obesity scholarship, the types of challenges faced by critical obesity scholars in higher education, and how these scholars are building community as a way of coping with challenges facing the emerging field.
\end{abstract}

\section{Résumé}

Puisque les institutions d'enseignement post-secondaire sont de plus en plus perçues comme des lieux de promotion de la santé, les acteurs universitaires attirent l'attention sur la façon dont l'approche contemporaine de l'Occident, axée sur le poids corporel, renforce les attitudes discriminatoires et les discours nocifs sur le surplus de poids. En découle l'importance d'effectuer des recherches favorisant des stratégies d'enseignement et d'apprentissage qui soient déconnectées de l'image corporelle. Ainsi, la présente étude 
analyse les entrevues de 26 professeurs universitaires qui enseignent une approche critique des facteurs traditionnels liés à l'obésité et à la composition corporelle. Les résultats font la lumière sur l'émergence de la mission professorale quant à l'obésité grave, sur les défis que relèvent les chercheurs du domaine en enseignement supérieur, et sur la façon dont ces chercheurs se constituent une nouvelle communauté scientifique afin de surmonter les difficultés rencontrées par les acteurs de cette recherche en émergence.

\section{Introduction}

The recent signing of the Okanagan Charter (2015) at the International Congress on Health Promoting Universities and Colleges raises awareness of the role and responsibility of postsecondary institutions to promote health, beyond just training healthcare professionals. The charter suggests that complex global health challenges in society today will require highly innovative thinking and collaboration by all professionals. An example of such thinking is the emerging interdisciplinary field of critical obesity scholarship, which refers to all scholarship that challenges dominant obesity discourse such as fat studies, critical obesity studies, critical weight studies, critical geographies of body size, and health at every size.

Critical obesity scholarship draws attention to how weight-centred approaches to health fail to highlight more important social determinants of health (O’Hara \& Gregg, 2012). This scholarship also highlights how growing concerns about the "obesity epidemic" have led to a "shadow epidemic" (Daghofer, 2013) of negative attitudes, beliefs, assumptions, and judgements about larger body sizes that result in harmful stereotypes and stigmatization (Puhl \& Brownell, 2001). It has been shown that stigma based on weight (herein referred to as obesity stigma) results in poor body image, decreased self-esteem, depression, lower physical activity levels, emotional eating, disordered eating, avoidance of health care, challenges in school, and overall poor quality of life (Puhl \& Brownell, 2006). Obesity stigma also has significant implications in the areas of employment, health care, interpersonal relationships, media, and, notably, in education (Puhl \& Heuer, 2009).

In Canada, there is growing awareness of the negative consequences of obesity stigma and the need for strategies to reduce it in educational contexts (Canadian Obesity Network, 2011; Daghofer, 2013; Hospital for Sick Children, 2011). While much of the focus has been on $\mathrm{K}-12$ school settings, a growing body of critical obesity scholarship also points to the negative consequences of obesity stigma in higher education settings.

To date, obesity stigma in higher education has been shown to negatively affect students' experiences in higher education (Brown, 2012; Hetrick \& Attig, 2009; Kingkade, 2013). It has also been said to negatively influence graduate school admissions (Burmeister, Kiefner, Carels, \& Musher-Eizenman, 2013), tenure and promotion processes (Fisanick, 2006), instructor credibility (Bacon, 2009; Longhurst, 2012), and faculty development (Murray, 2005; Pausé, 2012). Researchers have also found significant obesity stigma among students within health-related programs, such as medicine (Phelan et al., 2014), nursing and psychology (Waller, Lampman, \& Lupfer-Johnson, 2012), nutrition (Puhl, Warton, \& Heuer, 2009), and kinesiology (Greenleaf, Martin, \& Rhea, 2008; O'Brien, Hunter, \& Banks, 2007), and it has been suggested that it also exists in outdoor education settings (Russell, Cameron, Socha, \& McNinch, 2013). 
Despite the growing evidence about the prevalence of obesity stigma in higher education, empirical studies of how to reduce obesity stigma remain limited (Daníelsdóttir, O'Brien, \& Ciao, 2010). The few studies that have been published have focused on interventions that (a) modify student knowledge and beliefs about health and obesity through lectures and written texts (see Diedrichs \& Barlow, 2011; Humphrey, Clifford, \& Morris, 2015), (b) promote empathy and acceptance through videos, first-person narratives, and experiential practices (see Cotugna \& Mallick, 2010; Gapinski, Schwartz, \& Brownell, 2006; Hague \& White, 2005; Hennings et al., 2007; Rukavina, Li, Shen, \& Sun, 2010), and (c) draw upon social pressure to change attitudes and beliefs (Puhl, Schwartz, \& Brownell, 2005; Stangor, Sechrist, \& Jost, 2001). However, the effectiveness of these approaches remains inconclusive.

In addition to obesity stigma intervention research, a handful of scholars have provided reflective accounts on their experience teaching courses that challenge the politics of obesity (Boling, 2011; Guthman, 2009; Tirosh, 2006), and some scholars have offered ideas that are informing a "fat pedagogy" (Cameron, 2015; Cameron et al., 2014; Fullbrook, 2012; Hopkins, 2011; Moola, Norman, Petherick, \& Strachan, 2014; Russell et al., 2013; Watkins \& Concepcion, 2014; Watkins, Farrell, Doyle-Hugmeyer, 2012; Watkins \& Doyle-Hugmeyer, 2013). Like other emancipatory and liberatory pedagogies (Friere, 1970; Giroux, 1997; hooks, 1994), fat pedagogy offers a complex and situated pedagogy that provides valuable insight into how power and oppression are being constructed by, in, and through body size.

While issues of race, class, sex, and (dis)ability have been taken up by critical scholars concerned with teaching diversity in higher education, weight-based oppression (what some have refered to as "sizeism"; Joanisse \& Synnott, 1999), has received less attention (Cameron et al., 2014). Drawing upon critical pedagogy as a theoretical lens (Darder, Baltodano, \& Torres, 2009; Monchinski, 2008), this study sheds light on the experiences of 26 scholars in higher education who are engaged in critical obesity scholarship, and the challenges facing the field. It concludes by arguing that administrators, educators, and researchers need to pay attention to how weight-based oppression is being enacted on everybody in Canadian university campuses and beyond.

\section{Research Design and Method}

This study is part of a larger study conducted from June to August 2013 that examined the experiences and pedagogies of faculty in higher education teaching full courses, class units, or components that included materials related to critical obesity scholarship (for other publications from the larger study see Cameron 2015a, 2015b). An initial participant list was created by identifying academic faculty who had published in the field, were part of professional networks, and served on relevant editorial committees (such as the Fat Studies Journal). Participants were contacted through publicly listed university email addresses, and only those who responded to the invitation to participate were contacted. Additional participants were recruited using snowball sampling, where participants involved in the study provided names of other potential participants. In total, 31 were recruited and five withdrew. In the end, 26 teaching faculty (23 females, three males) from five different Western countries and from a diverse range of disciplines participated in the study (see Table 1). 
Table 1.

An Overview of the Participant Characteristics in the Research Study

\begin{tabular}{|c|c|}
\hline Demographics & Participants \\
\hline Sex & Female $(n=23)$, Male $(n=3)$ \\
\hline Location & $\begin{array}{l}\text { Canada }(n=9), \text { United States }(n=11), \text { England }(n=2), \text { New Zealand } \\
(n=3), \text { and Australia }(n=1)\end{array}$ \\
\hline Science Disciplines & $\begin{array}{l}\text { Kinesiology }(n=4), \text { nutrition }(n=4), \text { medicine }(n=2) \text {, nursing }(n= \\
2), \text { psychology }(n=1)\end{array}$ \\
\hline $\begin{array}{l}\text { Social Sciences and } \\
\text { Humanities Disciplines }\end{array}$ & $\begin{array}{l}\text { Geography }(n=3), \text { sociology }(n=2), \text { education }(n=2) \text {, women's } \\
\text { studies }(n=2), \text { writing/rhetoric }(n=2) \text {, history }(n=1) \text {, community } \\
\text { studies }(n=1)\end{array}$ \\
\hline Years Teaching & $1-5$ years $(n=11), 6-10$ years $(n=5), 11+$ years $(n=10)$ \\
\hline $\begin{array}{l}\text { Teaching Experience } \\
\text { Related to Fat }\end{array}$ & $\begin{array}{l}\text { Full courses }(n=7), \text { full unit focused on fat }(n=2) \text {, infused fat into } \\
\text { classes }(n=16)\end{array}$ \\
\hline Body Size Identification & $\begin{array}{l}\text { Fat }(n=6) \text {, Fat identity (they identified as fat but had lost weight; } n= \\
\text { 4), "Innies" (in-between; } n=3) \text {, "Normal" weight and/or having thin } \\
\text { privilege }(n=13)\end{array}$ \\
\hline
\end{tabular}

Note. The information in this table could not be further broken down to protect confidentiality since doing so would make participants potentially identifiable given this is such a small research community.

Data for the study included course materials, semi-structured interviews, and field notes. Prior to conducting interviews, participants were asked to send course materials to help the researcher prepare and probe specific teaching experiences (i.e., course syllabi, PowerPoint files, lecture notes, and assignment outlines). The semi-structured phone and Skype interviews lasted between 60 to 120 minutes (Creswell, 2012; Merriam, 2002, 2009) and consisted of questions related to the participants' academic background, path into critical obesity scholarship, experiences with teaching critical obesity scholarship in higher education, and the specific pedagogical approach with regard to critical obesity scholarship.

Each interview was audio recorded, transcribed verbatim, and sent to the participant for member checking. Each participant was assigned a pseudonym for anonymity. After validating transcripts, the data were analyzed using thematic analysis and Lichtman's (2010) six-step coding process (initial coding, revisiting coding, developing categories, modifying categories, revisiting categories, moving from categories to concepts) with the assistance of ATLAS.ti 7.o. In total, 446 pages of interview transcripts, 1,890 pages of course materials, and 70 pages of field notes were used to triangulate the data. In addition, frequent debriefing with a colleague helped to reach an understanding of the emerging themes, which enhanced the credibility and trustworthiness of the study (Guba, 1981; Shenton, 2004).

\section{Results}

This section offers a descriptive analysis of the four main themes that emerged and related to the participants' experiences with critical obesity scholarship within higher education: 
1. how faculty became engaged in the field

2. what challenges they encountered teaching this topic

3. what challenges they faced as scholars inside and outside the classroom

4. how they developed a strong sense of community with other critical obesity scholars in order to sustain their work in the field

\section{Engaging with Critical Obesity Scholarship}

All participants shared experiences about how they discovered, connected to, and established community with others who were challenging dominant obesity discourse. All but three of the participants stated their professional interests in critical obesity scholarship stemmed from their life experiences. For most, critical obesity scholarship was both a personal and professional endeavour. Some participants noted how their own weight struggles illustrated that weight is not necessarily a marker of health. For example, Rhonda suffered from an eating disorder when she was younger and while she fit the "thin ideal" and was perceived as healthy, she realized she was far from healthy.

Others shared stories of witnessing close friends and family members policing their weight and their discomfort witnessing the harm caused by the weight-centred health paradigm. These experiences were enough to inspire them to reconsider critical obesity discourse. For example, Jennifer was influenced by her mother's negative experiences with weight:

I think, to be honest, my awareness of the impact of weight and body shape and size comes from my mother ... She remembers vividly always being picked last, not being very physically skilled, and always being called a cow.

Similarly, Evelyn spoke about how how her daughter has conveyed a new-found awareness of how vulnerable young girls are to dominant obesity discourse and beauty ideals:

My daughter is four and she's already started; when she was two she said something about ... It was really horrifying and it was around being pretty and I'm, like, oh my god, this is how it happens.

Others, like Ginette, spoke about how professional experiences gave them insights into the injustices enacted upon bodies, particularly in health fields, and how their training in higher education had not prepared them to think beyond the weight-centred health paradigm.

Participants also saw firsthand the harm being caused by the weight-centred health paradigm. As a dietician Nicole constantly witnessed the harmful effects of focusing on weight as a primary measure of health:

I remember one woman, particularly, [who] was eating about 800 calories a day and walking an hour a day and her weight didn't budge. The doctor didn't believe her and she would be in tears in my office. It was just terrible. Just the shame and the guilt ... yeah, it was just a horrible thing to be doing as I think about it now. I knew that there had to be a better way, but at that point I didn't know what it was. 
A number of participants identified specific moments in their academic careers when they were first introduced to critical obesity scholarship. For many, it was reading key texts such as Fat! So? by Marilyn Wann (1998), The Obesity Myth by Paul Campos (2004), and The Obesity Epidemic by Michael Gard and Jan Wright (2005). John, for example, discussed his general discomfort with how kinesiology had latched onto obesity science as a way to justify itself and how reading texts that brought critical approaches to bodies, weight, and health gave his discomfort a voice. Like John, other participants described their growing discomfort with the weight-centred health paradigm and how it propelled them into critical obesity scholarship. In addition to key scholars, participants also spoke of feeling inspired by activists and bloggers, such as Marilyn Wann, Marianne Kirby, and Lesley Kinzel, who have helped expose the politics of obesity. All these individuals have been instrumental in inspiring people to re-evaluate obesity discourses.

Regardless of how they came to be interested in critical obesity scholarship, all the participants expressed excitement about being involved in this study and being part of such an exciting and emerging field of scholarship. Rebecca said, "there's all kinds of exciting stuff out there. And really now, because it's a field where there's a lot happening all the time, it doesn't feel lonely anymore at all. It doesn't." Bella noted that the field of critical obesity scholarship is still relatively new to higher education. "Only 10 or 15 years ago, it was only activists, academics hadn't come on board as much." She was referring how other fields of academic studies (e.g., queer, feminist, and environmental) often follow social movements (Wann, 2009).

\section{Challenges Teaching Critical Obesity Scholarship}

Twenty-one participants shared experiences directly related to teaching critical obesity scholarship. For example, many of the participants talked about how students were unusually uncomfortable in classes that destabilized contemporary obesity discourse. Sarah, for instance, went so far as describe the different "camps" in her classes.

There are always people who are, like, "Yes, this is what I've been waiting for ..." They get very excited about it. Then there are the ones who sit there and you watch them. They're mulling it over and you can tell there's a dissonance there. Then there are the ones who stand up and say, "No, this can't be right. This is wrong."

June described how her students would not even acknowledge weight-based oppression, making it hard to teach: "My students were, like, 'What are you talking about? There's no such thing. We don't see this. Does that really happen? Someone's making that up." Some participants talked about how they could easily see resistance in the body language of their students. Alexa had observed that, "The minute that fat came up and I suggested that 'fat wasn't bad,' you could see them sit back. You could see their arms cross and you could see that their body language was very much, very resistant."

Some of the participants talked about how student assignments were a safe place for students to express their discomfort with the subject matter. However, Jennifer said that she would never use student journals again because they became a vehicle to fuel obesity stigma. Kuna, on the other hand, suggested that for precisely that reason student journals are an important vehicle to allow students to struggle with their resistance. She felt it 
helped the students "get out" some of the oppressive comments and thoughts, which she felt was an important part of the learning process.

Not only did participants share class activities that evoked strong responses by students but also they shared direct experiences with weight discrimination by students. Four participants spoke about how students would often use course evaluations to make egregious comments about the instructors' bodies and appearance, so much so that June stopped reading her evaluations altogether out of fear of what would be written:

I actually avoided reading my evaluations for this class because I was afraid something would be in there. The first time I ever taught a class, I had a student write about how my tan pants were horrible and that a fat woman should never wear them.

Autumn shared a similar experience, although the negative responses she received did not come from her own class: "After guest lecturing for a colleague, they received feedback on their evaluations saying that they shouldn't let people who 'promote obesity' come speak."

Participants also noted how students from different disciplines tend to react differently to learning about the politics of obesity. For example, participants in the health-related disciplines, such as medicine, nursing, psychology, and kinesiology, suggested that often the biomedical narratives about "obesity" are stronger in these disciplines and therefore students tend to be more invested in dominant health discourses that reinforce ideas of personal responsibility. As Rebecca suggested, obesity is often positioned as "the biggest problem facing the world, above war, inequality, and poverty," and students have had a limited exposure to critical perspectives. As someone who teaches students from various disciplines, Wendy said that her women's studies students are used to deconstructing discourses, whereas students in the health sciences struggle.

Typically the [students] that have come in from fields like kinesiology have a very strong sense of lifestyle determinants as the imperative defining health. So, their response to a critical social perspective is to say yes, but that person is making poor choices, or how do we direct things in a way that is going to get that person to diet, to get out and exercise more. So, it's really an individualistic, and what I might think of as a very reductionistic, approach to thinking about weight and weightism.

Participants also talked about how maturity plays a role, and that their older students with more life experience have generally been more open to critical perspectives, particularly in graduate degree programs.

\section{Challenges Doing Critical Obesity Scholarship}

While student resistance was evident, it was at an institutional level that participants faced the most common form of weight-based oppression. All participants shared experiences of both overt and covert weight-based oppression in higher education settings. Samantha captured it well when she said, "Universities can be harsh, unforgiving kinds of places, I think, if you're in any way different."

Many participants expressed how weight-based oppression is consistently and covertly enacted on the bodies of students, staff, and faculty. For example, Alexa spoke about how furniture at her university reinforces obesity discourse: “There are places that I can't 
fit into a chair or barely ... So, there's a lot of underlying or covert just simply not making room for me."Kuna talked about obesity stigma in terms of health insurance policies at her university: "We have to report our waist circumference and our weight, and if we refuse to report them, we pay higher premiums."

Samantha talked about how, after losing weight, she had the sense of having more credibility among her colleagues: “There's nothing you can put your finger on because nobody is going to say you're a fat woman, we're not really listening to you. But, you do feel it." While Alexa, Kuna, and Samantha provided examples of covert resistance, other participants identified many examples of overt resistance. Jessie shared an experience about how he has been discredited publicly.

There was once where somebody stood up in the middle of a presentation and turned their back on me and said to the audience, of which there were quite a few, that they shouldn't listen to anything I should say.

Brenda described an experience where someone called her department chair after a conference to question the credibility of her work. "She actually called up my department chair and told him I was spreading misinformation." June recounted an experience with a senior faculty member who questioned the legitimacy of critical obesity scholarship:

We started talking about my fat studies work and she said, "You can't put this on your CV. Nobody will take you seriously." I said, "Well, that's what I do. That's the framework I come from and that's sort of what guides my work. What would you recommend that I use?" She responded by saying, "Well, we call that monstrous bodies or you have to frame it as disability studies" and she had a couple of other suggestions. So, I was, like, "So, you're just basically saying the whole field is invalid and therefore I would never be taken seriously.

Some participants also talked about having to face challenges with politics and funding. For example, Jessie said "as far as funding goes, I can't prove it, but . . if you're not declaring war on obesity then you really do narrow down the kind of areas that you can get funding from." Participants also talked about the resistance they have faced in publishing. Samantha described a particularly horrifying experience:

Even though I didn't know who the reviewers were, they had identified who I was because it was autobiographical, I suppose. They wrote in their feedback, they wrote things like, "[She] should put this paper back in the drawer for a few years until she gains the weight again." Wow. When you open yourself up to putting in the personal, I guess you sometimes get personal back in a way that you don't want or anticipate.

Four participants specifically spoke of their reduced job marketability due to their work challenging dominant obesity discourse. For example, Elizabeth suggested that she does not have a full-time position yet because she took a critical approach to fatness in her dissertation:

I talked about this with my dissertation advisor and she feels, yes, that [my fat studies topic] has impacted my job marketability. I think that she may be right. Her 
theory is that in some topics that are social justice issues it's very clear what side to be on. So, if we teach about racism or government practices that were normative around race, Aboriginality, around gender, people clearly know that's wrong. But because the discourse on weight is so much on the side of the obesity epidemic in general, because [talking about] the body is very uncomfortable, it's a very uncomfortable topic to bring into the classroom.

Throughout the interviews, participants talked about needing to be careful about how they framed fatness in higher education, particularly those who were in the sciences. Many felt a tension between wanting to be critical and also needing to fit into university agendas that promote dominant discourses. John compared doing critical obesity scholarship to "coming out of the closet."

\section{Developing a Critical Obesity Scholarship Community}

As a result of the growth in the field of critical obesity scholarship, participants in this study felt a growing sense of community. Although there are certainly differences within the field, participants expressed the importance of establishing a community of scholarship focused on critiquing dominant notions of obesity. Based on her own experiences, Sharon stated that even having just one other person with similar interests can help build a sense of community. Just as Sharon gained strength from not being the only one offering a critical perspective on fatness, Alexa, too, felt that establishing community is key to the success of the field, given the constant resistance critical obesity scholars face in working to disrupt obesity discourse:

I believe in community. I believe the only way that we can survive this stuff is with community. In fact, that's one of the quotes I use of bell hooks, to live in the margin requires "a community of resistance.

Ginette also spoke about the integral role community played in her experiences with tenure when she faced what she called "the darker" side of higher education:

I was pretty lucky that I had support. I have incredibly supportive colleagues outside of my department and an incredibly supportive union who stood beside me and fought hard and defended me against a lot of pretty bad things.

In sharing their experiences with critical obesity scholarship, five participants also talked about the changing landscape and how, while change can be slow and difficult, sizeism is starting to gain traction within higher education. For example, Bella suggests that while other social justice issues, such as gender, race, and class have become more common in higher education, critical obesity scholarship is so new and provocative that it immediately challenges students to think differently:

I think, just in terms of where we are in history about talking about this topic, just raising it, it's like shooting fish in a barrel now. Just raising it and talking about it is to teach them something. Nobody's ever talked to them this way before. It might be like teaching LGBTQ studies twenty or thirty years ago, or something like that. 
Overall, participants expressed a sense of hope for the future and felt that the work that they were doing within higher education had deep purpose and meaning. As Lydia stated, "As more and more every day fat people are less willing to be treated like second-class citizens because of their weight, then hopefully it will become something that's a regular part of the discourse."

\section{Discussion and Conclusion}

The results of this study support existing literature that weight-based oppression in higher education is a significant current social justice issue. The importance of identifying strategies for reducing obesity stigma in higher education, therefore, cannot be understated, given the role higher education can play in forming (or changing) attitudes and beliefs about obesity, bodies, and health. For example, academic researchers are increasingly funded by private companies from the health service economy (King-White, Newman, \& Giardina, 2013), leading Oliver (2006) to claim that "academic obesity researchers and scientists often exaggerate or play up the dire impact of obesity to help them secure more research funding" (p. 619). At the same time, universities increasingly promote themselves as diversity-focused (Mitchell, 2003) and equity-conscious (Ahmed, 2007) in order to be, or to appear to be, more socially responsible. Some critical scholars argue that such rhetoric merely serves to obscure the oppressions that persist (Wagner \& Yee, 2011). Weight-based oppression is one such example.

All participants shared experiences about student or institutional resistance while working in this field, and approximately $80 \%$ reported that significant resistance has altered their career paths. Participants offered insights into how higher education reinforces dominant obesity discourse through teaching, tenure, funding, publishing, supervising, and positionality (i.e., how comfortable they feel "coming out" with their theoretical, ideological, and pedagogical perspectives). Yet despite their challenges, this study offers insights into why scholars continue to pursue critical obesity scholarship and the challenges that other social justice fields have faced.

While the findings in this study may not represent the experiences of all faculty teaching critical obesity scholarship in higher education, they offer two important contributions to higher education and diversity literatures. First, participants clearly articulated the important and various ways critical obesity scholarship is emerging in the literature and in the university classroom. While some participants focused on problematizing the science, morality, and politics of the "obesity" epidemic, others focused on highlighting fat subjectivity, embodiment, and acceptance and how it brought attention to the lives of those targeted by anti-obesity initiatives and weight-loss regimes, with special focus on the role of activism and advocacy. While different foci, perspectives, and approaches in the field may create certain ontological and ideological tensions (Cooper, 2010; Lupton, 2013), it is clear that a growing sense of connection and purpose within the field is emerging in new and interesting ways that speak to its interdisciplinarity and relevancy in today's culture.

To conclude, there are two main ways in which this study contributes to the higher education literature. First, this study offers insights into how critical obesity scholarship is helping to "raise consciousness" around the systemic discrimination occurring within higher education that relates to weight and body size. It mirrors Monaghan, Colls, and Ev- 
ans', (2013) conclusion that critical obesity scholars are overwhelmingly "united in their refusal to simply reproduce, legitimate, and endorse biomedical narratives" (p. 251). This common purpose gives the participants hope in their continued efforts to raise awareness about weight-based oppression and the need for more size-inclusive teaching and learning environments to support people of all shapes and sizes.

Second, this study highlights the ways in which scholars who challenge obesity discourse face significant resistance both inside and outside the classroom. This has not only been shown to affect careers but also it may affect the emerging field of critical obesity scholarship, given the potential for fatigue and burnout. While critical obesity scholarship has provided important critiques that have led to new understanding of fatness, more scholarship is needed in higher education that specifically highlights ways to learn, teach, work, and create spaces that embrace everybody. As Wann (2009) argues,

[u]ntil the fat studies bookshelf is longer than the diet bookshelf. . [ [t]here is more than enough fat studies work for all of us to do: connections to make, freedom to envision, liberation to embody, and implications to comprehend." (p. xxii)

To date most of the literature around critical obesity scholarship in higher education has focused on reducing or eliminating obesity stigma. While undoubtedly important, this study shows that critical obesity scholarship in higher education needs to improve the experiences of everybody in higher education (i.e., students, faculty, and staff) and challenge weight-based oppression and the systems that serve to reinforce it. This study highlighted some of the broad perspectives and experiences of faculty teaching critical obesity scholarship, but more work needs to be done to specifically understand the complexity and nuanced experiences of faculty within different disciplines (sciences versus social sciences and humanities), with varying years of teaching experience (tenure versus non-tenured), and with different bodies (fat versus thin). Future research might help to better understand specifically how to support faculty doing critical obesity scholarship in research and teaching.

\section{Acknowledgements}

Firstly, I would like to thank the Social Sciences and Humanities Research Council of Canada (SSHRC) who funded this research study. Secondly, I am indebted to the 26 individuals who participated in this study and shared their stories, experiences, and insights with me. Lastly, I am indebted to Drs. Teresa Socha, Connie Russell, Gerald Walton, Joe Barrett, Lori Chambers, and Geneviève Rail for their support and invaluable feedback in all stages of this research study.

\section{References}

Ahmed, S. (2007). You end up doing the document rather than doing the doing: Diversity, race equity and the politics of documentation. Ethnic and Racial Studies, 3O(4), 590-609.

Bacon, L. (2009). Reflections on fat acceptance: Lessons learned from privilege. Speech, National Association to Advance Fat Acceptance. Retrieved from http://www. lindabacon.org/Bacon_ThinPrivilegeo80109.pdf 
Boling, P. (2011). On learning to teach fat feminism. Feminist Teacher, 21(2), 110-123.

Brown, H. (2012). Fashioning a self from which to thrive: Negotiating size privilege as a fat woman learner at a small liberal arts college in the Midwest (Doctoral dissertation). Retrieved from http://gradworks.umi.com/35/40/3540565.html

Burmeister, J. M., Kiefner, A. E., Carels, R. A., \& Musher-Eizenman, D. R. (2013). Weight bias in graduate school admissions. Obesity, 21(5), 918-920.

Cameron, E. (2015a). Toward a fat pedagogy: A study of pedagogical approaches aimed at challenging obesity discourse in post-secondary education. Fat Studies: An Interdisciplinary Journal of Body Weight and Society, 4(1), 28-45.

Cameron, E. (2015b). Teaching resources for post-secondary educators who challenge dominant "obesity" discourse. Fat Studies: An Interdisciplinary Journal of Body Weight and Society, 4(2), 212-226.

Cameron, E., Oakley, J., Walton, G., Russell, C., Chambers, L., \& Socha, T. (2014). Moving beyond the injustices of the schooled healthy body. In I. Bogotch \& C. Shields (Eds.), International handbook of educational leadership and social (in)justice (pp. 687-704). New York: Springer.

Campos, P. (2004). The obesity myth: Why America's obsession with weight is hazardous to your health. New York, NY: Penguin.

Canadian Obesity Network (CON-RCO). (2011). Canadian summit on weight bias and discrimination summit report. Canadian Obesity Network. Retrieved from http://www. obesitynetwork.ca/files/Weight_Bias_Summit_Report.pdf

Cooper, C. (2010). Fat studies: Mapping the field. Sociology Compass, 4(12), 10201034 .

Cotugna, N., \& Mallick, A. (2010). Following a calorie-restricted diet may help in reducing healthcare students' fat-phobia. Journal of Community Health, 35(3), 321-4.

Creswell, J. (2012). Educational research: Planning, conducting, and evaluating quantitative and qualitative research (4th ed.). Boston, MA: Pearson Education.

Daghofer, D. (2013). From weight to well-being: Time for shift in paradigms? A discussion paper on the inter-relationships among obesity, overweight, weight bias, and mental well-being. Vancouver, BC: [BC] Provincial Health Services Authority. Retrieved from http://www.phsa.ca/population-public-health-site/Documents/W2WBTechnicalR eport_20130208FINAL.pdf

Daníelsdóttir, S., O’Brien, K., \& Ciao, A. (2010). Anti-fat prejudice reduction: A review of published studies. Obesity Facts, 3(1), 47-58.

Darder, A., Baltodano, M., \& Torres, R. (2009). Critical pedagogy: An introduction. In A. Darder, M. Baltodano, \& R. Torres (Eds.), The critical pedagogy reader (2nd ed.), pp. 1-20). New York, NY: Routledge.

Diedrichs, P. C., \& Barlow, F. K. (2011). How to lose weight bias fast! Evaluating a brief anti-weight bias intervention. British Journal of Health Psychology, 16(4), 846-861. 
Fisanick, C. (2006). Evaluating the absent presence: The professor's body at tenure and promotion. The Review of Education, Pedagogy, and Cultural Studies, 28(3-4), 325-338.

Freire, P. (1970). Pedagogy of the oppressed. New York, NY: Continuum.

Fullbrook, A. (2012). You have nothing to lose! Using culturally relevant pedagogy in secondary education to make space for body acceptance (Masters thesis). Retrieved from https://tspace.library.utoronto.ca/bitstream/1807/33650/1/Fullbrook_Ashley_C_201211_ MA_thesis.pdf

Gapinski, K., Schwartz, M., \& Brownell, K. (2006). Can television change anti-fat attitudes and behaviour? Journal of Applied Biobehavioural Research, 11(1), 1-28.

Gard, M., \& Wright, J. (2005). The end of the obesity epidemic. London, UK: Routledge.

Giroux, H. (1997). Pedagogy and the politics of hope: Theory, culture, and schooling. Boulder, CO: Westview Press.

Greenleaf, C., Martin, S., \& Rhea, D. (2008). Fighting fat: How do fat stereotypes influence beliefs about physical education? Obesity, 16(2), S53-S59.

Guba, E. G. (1981). Criteria for assessing the trustworthiness of naturalistic inquiries, Educational Communication and Technology Journal, 29, 75-91.

Guthman, J. (2009). Teaching the politics of obesity: Insights into neoliberal embodiment and contemporary biopolitics. Antipode, 41(5), 1110-1133.

Hague, A., \& White, A. (2005). Web-based intervention for changing attitudes of obesity among current and future teachers. Journal of Nutrition Education and Behaviour, 37(2), 58-66.

Hennings, A., Hilbert, A., Thomas, J., Siegfried, W., \& Rief, W. (2007). Reduction of stigma against obese people: Effects of an educational film. Psychotherapie Psychosomatik Meizinische Psychologie, 57(9-10), 359-363.

Hetrick A., \& Attig, D. (2009). Sitting pretty: Fat bodies, classroom desks, and academic excess. In E. Rothblum \& S. Solovay (Eds.), The fat studies reader (pp. 197-204). New York, NY: NYU Press.

hooks, b. (1994). Teaching to transgress: Education as the practice of freedom. New York, NY: Routledge.

Hopkins, P. (2011). Teaching and learning guide for: Critical geographies of body size. Geography Compass, 5(2), 106-111.

Hopkins, P. (2012). Everyday politics of fat. Antipode, 44(4), 1227-1246.

Hospital for Sick Children. (2011). National prevention strategy meeting: Linking research, practice and policy in the prevention of weight-related disorders. Retrieved from http://www.ocoped.ca/PDF/NPS_Discussion_Document_Nov_2011.pdf

Humphrey, L., Clifford, D., \& Morris, M. N. (2015). Health at every size college course reduces dieting behaviors and improves intuitive eating, body esteem, and anti-fat attitudes. Journal of Nutrition Education and Behavior, 47(4), 354-360.. 
Kingkade, T. (2013, July 2). Geoffrey Miller claims mocking obese people on Twitter was research: University disagrees. Huffington Post Website. Retrieved from http://www. huffingtonpost.com/2013/o7/o2/geoffrey-miller-twitter-obese-research_n_3531376.html

King-White, R., Newman, J. I., \& Giardina, M. D. (2013). Articulating fatness: Obesity and the scientific tautologies of bodily accumulation in neoliberal times. Review of Education, Pedagogy, and Cultural Studies, 35(--), 79-102.

Joanisse, L., \& Synnott, A. (1999). Fighting back: Reactions and resistance to the stigma of obesity. In J. Sobal \& D. Maurer (Eds.), Interpreting weight: The social management of fatness and thinness. New York, NY: Aldine de Gruyter.

Lichtman, M. (2010). Qualitative research in education: A user's guide. Thousand Oaks, CA: Sage.

Longhurst, R. (2012). Becoming smaller: Autobiographical spaces of weight loss. Antipode, 44(3), 871-888.

Lupton, D. (2013). Fat. New York, NY: Routledge.

Merriam, S. B. (2002). Qualitative research in practice: Examples for discussion and analysis. San Francisco, CA: Jossey-Bass.

Merriam, S. B. (2009). Qualitative research: A guide to design and implementation. San Francisco, CA: Jossey-Bass.

Mitchell, K. (2003). Educating the national citizen in neoliberal times: From the multicultural self to the strategic cosmopolitan. Transactions of the Institute of British Geographers, 48(4), 387-403.

Monaghan, L., Colls, R., \& Evans, B. (2013). Obesity discourse and fat politics: Research, critique and interventions. Critical Public Health, 23(3), 249-262.

Monchinski, T. (2008). Critical pedagogy and the everyday classroom. New York, NY: Springer.

Moola, F. J., Norman, M. E., Petherick, L., \& and Strachan S. (2014). Teaching across the lines of fault in psychology and sociology: Health, obesity and physical activity in the Canadian context. Sociology of Sport Journal 31(2), 202-227.

Murray, S. (2005). (Un/be)coming out? Rethinking fat politics. Social Semiotics, 15(2), 153-163.

Okanagan Charter: An International Charter for Health Promoting Universities and Colleges (2015). Kelowna, BC: International Conference on Health Promoting Universities and Colleges / VII International Congress. Retrieved from http:// internationalhealthycampuses2015.sites.olt.ubc.ca/files/2015/10/Okanagan_Charter_ Oct_6_2015.pdf

O’Brien, K. S., Hunter, J. A., \& Banks, M. (2007). Implicit anti-fat bias in physical educators: Physical attributes, ideology and socialization. International Journal of Obesity, 31(2), 308-314.

O'Hara, L., \& Gregg, J. (2012). Human rights casualties from the "war on obesity": Why focusing on body weight is inconsistent with a human rights approach to health. Fat Studies, 1(1), 32-46. 
Oliver, J. (2006). Fat politics: The real story behind America's obesity epidemic. New York, NY: Oxford University Press.

Pausé, C. (2012). Live to tell: Coming out as fat. Somatechnics, 2(1), 42-56.

Phelan, S. M., et al. (2014). Implicit and explicit weight bias in a national sample of 4,732 medical students: The medical student CHANGES study. Obesity, 22(4), 12011208.

Puhl, R., \& Brownell, K. (2001). Bias, discrimination, and obesity. Obesity Research, 9(12), 788-905.

Puhl, R., \& Brownell, K. (2006). Confronting and coping with weight stigma: An investigation of overweight and obese adults. Obesity, 14(10), 1802-1815.

Puhl, R., \& Heuer, C. (2009). The stigma of obesity: A review and update. Obesity, 17(5), 941-964.

Puhl, R., Schwartz, M., \& Brownell, K. (2005). Impact of perceived consensus on stereotypes about obese people: A new approach for reducing bias. Health Psychology, 24(5), 517-525.

Puhl, R., Wharton, C., \& Heuer, C. (2009). Weight bias among dietetics students: Implications for treatment practices. Journal of the American Dietetic Association, 109(3), 438-444.

Rukavina, P., Li, W., Shen, B., \& Sun, H. (2010). A service learning based project to change implicit and explicit bias toward obese individuals in kinesiology pre-professionals. Obesity Facts, 3(2), 117-126.

Russell, C., Cameron, E., Socha, T., \& McNinch, H. (2013). "Fatties cause global warming": Fat pedagogy and environmental education. Journal of Canadian Environmental Education, 18, 27-45.

Shenton, A. K. (2004). Strategies for ensuring trustworthiness in qualitative research projects. Education for Information, 22(2), 63-75.

Stangor, C., Sechrist, G., \& Jost, J. (2001). Changing beliefs by providing consensus information. Personality and Social Psychology Bulletin, 27(4), 486-496.

Tirosch, Y. (2006). Weighty speech: Addressing body size in the classroom. Review of Education, Pedagogy, and Cultural Studies, 28(3-4), 267-279.

Wagner, A., \& Yee, J. Y. (2011). Anti-oppression in higher education. Canadian Social Work Review, 28(1), 89-105.

Waller, T., Lampman, C., \& Lupfer-Johnson, G. (2012). Assessing bias against overweight individuals among nursing and psychology students: An implicit association test. Journal of Clinical Nursing, 21(23-24), 3504-3512.

Wann, M. (1998). Fat! So? Because you don't have to apologize for your size. Berkley, CA: Ten Speed Press.

Wann, M. (2009). Fat studies: An invitation to revolution. In E. Rothblum \& S. Solovay (Eds.), The fat studies reader (pp. ix-xxv). New York, NY: NYU Press. 
Watkins, P. L., \& Concepcion, R. Y. (2014). Teaching health at every size to health care professionals and students. In E. Glovsky (Ed.). Wellness not weight: Motivational interviewing and health at every size (159-169). San Diego, CA: Cognella Academic.

Watkins, P. L., \& Doyle-Hugmeyer, D. (2013). Teaching about eating disorders from a fat studies perspective. Transformations: The Journal of Inclusive Scholarship and Pedagogy, XXIII(2), 177-188.

Watkins, P. L., Farrell, A., \& Doyle-Hugmeyer, A. (2012). Teaching fat studies: From conception to reception. Fat Studies: An Interdisciplinary Journal of Body Weight and Society, 1(2), 180-194.

\section{Contact Information}

\section{Erin Cameron \\ School of Human Kinetics and Recreation \\ Memorial University \\ ecameron@mun.ca}

Erin Cameron is an assistant professor in the School of Human Kinetics and Recreation at Memorial University. As a retired professional athlete and public speaker on health and wellness, her research interests span across the fields of sport development, health and physical education, health promotion, and health pedagogy. Erin's most recent research examines strategies to promote positive body image and self esteem. Through her work, Erin endeavors to create safe spaces for everyBODY, regardless of weight, shape, and size, to pursue active and healthy lives. 